\title{
Pailazogintza soziohezitzailea: praktika pedagogiko komunitarioa
}

\author{
The socioeducational clown: a comunity pedagogical practice \\ Ainhoa Gana Dañobeitia, Asier Huegun Burgos* \\ Hezkuntza, Filosofia eta Antropologia Fakultatea \\ UPV/EHU
}

LABURPENA: Artikulu honek pailazogintzak hezkuntza-tresna gisa dituen ahalmenetan eta aukeretan sakontzea du helburu. Horretarako, Euskal Herriko pailazo-talde bat hartu da ikerketarako erreferente moduan, bertako partaideekin elkarrizketa sakonak eta eztabaida taldeak egituratuz. Pailazo sozio-hezitzailearen sorrera eta eginkizuna sakon aztertu dugu hainbat eta hainbat erreferentzia bibliografikoetan arakatuz eta oinarrituz. Pailazo soziohezitzailearen ikuspegian eta haren ezaugarrietan jarri da arreta batez ere, hezkuntza tresna gisa azalduz, eta hezkuntzan eragiteko bitarteko moduan agertuz. Horren guztiaren ondotik emaitzak eta ondorioak azaltzen ditugu, non ikus dezakegun ikertu den pailazo-taldeak eredu hezitzaile oso bat garatu duela eta hainbat ezaugarri barnebiltzen dituela.

GAKO-HITZAK: pailazo soziala, gizarte eraldaketa, euskara, herrigintza, unibertsitate-hezkuntza.

ABSTRACT: This article aims to deepen the competences and possibilities of the clown as an educational tool. For this, a group of clowns from the Basque Country has been taken as a point of reference for research, focusing on in-depth interviews and focus group with its members. The creation and role of the social clown has been widely analyzed and explored through numerous bibliographical references. The focus has been placed, above all, on the figure of the socio-educational clown and on its characteristics as an educational tool. Emphasis is placed on the possibilities that the socio-educational team has for influencing people's educational processes. After all, we explain the results and conclusions, where we can see that the group of clowns studied has developed their own educational model where we find different characteristics of their own.

KEYWORDS: social clown, social change, Basque language, community development, university education

* Harremanetan jartzeko / Corresponding author: Asier Huegun Burgos. UPV/EHU. Hezkuntza, Filosofia eta Antropologia Fakultatea / Facultad de Educación, Filosofía y Antropología (HEFA). Tolosa hiribidea, 70. E-20018. Donostia/San Sebastián - asier.huegun@ehu.eus - http://orcid.org/0000-0003-0703-0766

Nola aipatu / How to cite: Gana Dañobeitia, Ainhoa; Huegun Burgos, Asier. (2018). «Pailazogintza soziohezitzailea: praktika pedagogiko komunitarioan; Tantak, 30(2), 41-61. (https://doi.org/10.1387/tantak.20459)

Jasotze-data: 2018/01/31; Onartze-data: 2018/04/19.

ISSN 0214-9753 - elSSN 2444-3581 / (c) 2018 UPV/EHU

(c) (i) Obra hau Creative Commons Atribución 4.0 Internacional-en lizentziapean dago 


\section{PAILAZO SOZIOHEZITZAILEA: HEZKUNTZA-ERAGILEA}

Gure uste sendoa da hezkuntza ez-formaleko hainbat eremu ikertzeke daudela, besteak beste, pailazogintzarekin lotuta daudenak, pailazogintzaren eta hezkuntzaren arteko lotura, hain zuzen ere. Hau da, heziketarako tresna den arte modu horrek zer-nolako eredu pedagogikoa sortzen duen, zein diren beren ezaugarriak eta zer-nolako ekarpenak egiten dizkion hezkuntzari. Kezka horretan du abiapuntua lan honek, beraz.

Azken hamarkadetan pailazogintzak bilakaera izan du, are gehiago euskal pailazogintzak, eta sortu diren pailazo-talde askoren artean ditugun Takolo, Pirritx, Porrotx eta Marimotots pailazoak izan dira ikergai lan honetan, hain zuzen ere. Gauzak horrela, ikerketak galdera honi erantzutea du xede: Zein helburu eta ezaugarri ditu ikergai den euskal pailazo-taldearen pailazogintzak? Iker-galdera horri erantzun ahal izateko, herrigintzatik eta euskalgintzatik sortu den pailazo-talde honek sorreratik gaur arte izan dituen aldaketak aztertu dira, eta pailazogintza dela medio sortu duten proiektu pedagogiko berria ikertu da. Hori gauzatzeko elkarrizketa sakonak eta focus group teknika kualitatiboak erabili dira.

Eredu hezitzaile horren ezaugarriak identifikatu dira, eta balizko eredu horrek hezkuntzari egiten dion ekarpena interpretatu da, zeina heziketarako baliabide emankorra dela ondorioztatu dugun, baita pailazoak eraldaketarako tresna izatera irits daitezkeela ere.

\subsection{Pailazoaren definizioa eta konnotazioa}

Pailazoaren ikuspegi historikoa eta bilakaera zein izan den zehazteak lanaren iturri teorikoak kokatzen lagunduko digu. Zenbait agitalpenen arabera, diziplina artistiko hau definitzen duen termino unibertsaltzat hartzen da clown terminoa (Crowther, 1979; Nicoll, 1977; Sáinz, 1990). Dena den, lanbide honetan parte hartzen dutenen artean ez dago akordio adostu bat pailazo eta clown terminoen artean desberdintasunik determinatzen duenik (Ros, 2015b). Hortaz, asko direnez pailazo mota ezberdinek landu behar izan dituzten abileziak, zertaz ari gara pailazo hitza erabiltzean?

Historikoki, pailazoak helburu sinple eta argi bat izan du: dibertitzea, entretenitzea eta barre eginaraztea (Jara, 2011). Hala ere, ez dago pailazoaren definizio osotua azaltzen duen testurik. Izan ere, historian zehar pailazo mota ezberdinak (arlekin, saltinbanki, bufoi, oliver, augusto, kontraugusto, aurpegi-zuri, pierrot, politxinela, tony, komiko, trobadore, tramp, titiritero, bolatinero, mimo, mesie loyal, txerpolari, clown, juglare eta abar) egon dira munduan eta pailazo horien ikuskizunetako portaera desberdina izan da. Hortaz, termino hauez guztiez hitz egitean, pailazoaz ariko gara. Honek esan nahi du, pailazoaz (bere barietate guztiak aintzat harturik) hitz 
egitean, bere mundua ikusteko era zabalduz, umorearen bitartez ikusleen emozioetan eragin nahi duen pertsonaz ari garela.

Dena den, pailazoa ez da ofizialki ongi ikusia izan; eta barregarritzat (bere konnotazio negatiboan) eta tranpatitzat hartua izateaz gain, gutxietsia, zentsuratua eta baztertua ere izan da hainbat sasoitan. Fok (2008) dioen bezala, ordea, pailazogintza ez da tontakeria bat, artista hauen lana konstantea, diziplinatua eta arduratsua dela azpimarratzen du, eta pailazoak bere eraginkortasuna eta konpromiso politikoa galdu duela deritzo. Eta aurrekoaren antzera, Medina eta Citlallik (2015) ere pailazoaren eginkizun soziala, politikoa eta antropologikoa aintzat hartzen ez dela diote.

Baina Ceballosek (1999) serioki hartzen du pailazoaren ahalmen komikoa, bere gorputz osoaz baliatuz, pailazo batek gizakion emozioetan efektu komikoa izan dezakeela ondorioztatzen baitu. Gainera, Dominguezek (2015) aipatzen duen bezala, pailazoak munduan zehar bere balioaren eta ospearen hazkundea nabaritu du eta fenomeno hau kultura ongizatearen parte ere bilakatu da. Hori dela eta, nekez esan daiteke pailazoaren lana sinplea denik.

Laburbilduz, zer litzateke, beraz, pailazoa izatea? Guarnizok (2013) definitu bezala, pailazoak gizartearengan eragin dezake bere balioak umorearen bidez transmitituz. Halaber, irakasteko eta sentsibilizatzeko gai da pailazoa, eta gainerakoen pentsamenduak eraldatu ditzake. Pailazoak gaitasun pertsonal eta kolektiboak indartuko dituzten balioak eta emozioak transmititu eta estimulatzen ditu (Ros eta Úcar, 2013). Horrenbestez, pailazogintza autoezagutza bermatzen duen diziplina artistikotzat har daiteke, zeina bestearekiko zintzotasunean, errespetuan eta onarpenean oinarrituriko ikaskuntzan oinarritzen den. Izan ere, pailazogintzaren bidez, norbere buruarekiko onarpenak gainerakoak onartzea ere eragiten du, barrean eta umorean oinarrituriko metodologia baten oinarrituta (López, 2016).

Hainbatetan pailazoaren lanaren garapena zirkuaren barruan kokatu da, eta gaur egun ere, horren aztarnak baditugu, pailazoa bera eta zirkua tresna pedagogiko moduan hartu izan baitira hainbat eremutan. Horren adibide da Kataluniako eredu bat: Bidó de Nou Barris elkarteak kudeaturiko Ateneu Popular 9 Barris plataformak eskaintzen duen prestakuntza artistiko eta soziala. Zirkua ardatz zentraltzat izanik eta zirkuko tailer batzuk antolatzen hasi ondoren, plataforma horrek zenbait ekimen aurrera eraman ditu auzokideen parte-hartzearen bidez, eta testuingurua hobetzeko tresna komunitario bilakatu dute zirkua (Alcántara, Llotje eta Lopez, 2009).

Zirkua komunitatea hezteko erabiltzeko modu horrek garapena eta isla eduki dezake hezkuntzan; hots, zirkuak gizartean, kulturan eta heziketan eragina izan badu. Circo en acción (2017) proiektuaren arabera, inportantea litzateke arte eszeniko hau hezkuntzako esparru ezberdinetan abiaraztea; izan ere, adierazpenari eta sormenari ateak zabaltzeko balio du, hiritartasunean oinarrituriko balioetan, autonomian eta erantzukizunean oinarrituz. Era berean, proiektu honek dio, zirku-artearen bidez, ikastetxeak 
ikasleen jolaserako, topaketarako eta hartu-emanetarako espazio bilakatu daitezkeela, komunitate osoaren koordinazioaz, berdinen arteko elkartasunaren garapena sustatu dezakeelarik. Hortaz, Circo en acción proiektuak azaltzen duenez, ikastetxeetan erants daitekeen tresna pedagogikoa ere badugu zirkua, eta proiektu honek ikastetxea inklusio sozialerako leku paregabea dela ondorioztatzendu.

Zirku sozial mota horren helburu bertsuak ditu Zapalduaren Antzerkia deritzon antzerki mota berriak. Freireren Zapalduaren Pedagogiarekin jarraikiz, haren pentsamenduan eta praxian oinarrituz eta baita Brechten antzerkigintza motan oinarrituz, Zapalduaren Antzerkia sortu zuen Augusto Boal dramaturgo eta gizarte hezitzaileak, teknika dramatiko ezberdinez baliatuz, gizarteko injustiziak eta egoera latzak salatzeko balio duen antzerki mota berria, alegia (Boal, 2011).

Antzerkigintzaren bidezko praktika pedagogiko berritzaile honek, zapalduak direnen mesedetan buruturiko sistema hezitzaile bat proposatzen du. Gauzak horrela, Freirek (2005) proposatzen duen kontzientziazioaren bidezko pedagogiarekin bat dator arte teknika hau, izan ere, Zapalduaren Pedagogian norbanako oro bere hezkuntzaren protagonista den bezalaxe, Zapalduaren Antzerkian Boalek ere denok irakatsi eta denok ikasi ahal dugula uste du, beti ere horizontaltasunean oinarrituriko harremanen bidez bada, hau da, denok maila berean egonik, zapaltzaile eta zapaldurik egon gabe, aldamenekoa errespetatuz (Molina, 2005).

\subsection{Pailazogintzaren funtzioak}

Pailazoaren, zirkuaren eta antzerkiaren inguruko ideiok balio digute pailazo sozialaren ezaugarriak zedarritzeko eta argitzeko; izan ere, Ros eta Úcar (2013) autoreek azaldu bezala, pailazo sozialak beste zenbait pailazo biltzen ditu bere baitan (komunitarioa, humanitarioa, errebeldea eta gizarte eta hezkuntzako eremukoa):

- Komunitarioa: komunitatera hurbiltzeko eta komunitatean inplikatzeko helburuarekin, jolas komiko-poetikoak burutzen dituen agente artistikoa.

- Humanitarioa: prestakuntzaren edota ikuskizunen bidez laguntza humanitarioa burutzen duena, eremu kaltetuetan giza baldintzak hobetzeko xedearekin.

- Errebeldea: desobedientzia zibilaz eta parte-hartze politikoaz baliatuz barrea erabiltzen duena; botere hierarkikoa, belikoa eta militarra apurtzeko asmoz.

- Gizarte eta hezkuntzako eremukoa edo soziohezitzailea: gizarte eta hezkuntzako eremuko prozesuen bidez, komunitatearen garapena sustatzen du bere dimentsio guztietan: pertsonala, soziala edo komunitarioa eta kritikoa. 


\subsubsection{Pailazo soziohezitzailea}

Hezkuntzaren ikuspegitik pailazo soziohezitzailean jarri dugu arreta. Beraz, gizarte eta hezkuntzako eremuko pailazogintzaz ari garenean, hezkuntza bereziaren eta nagusien, osasunaren, ingurugiroaren eta animazio soziokulturalaren hezkuntzaz ari garela, herritartasunaren hobekuntza eta aldaketa soziala bermatzeko xedea duen pailazogintzaz, hain zuzen ere (Ros, 2015a).

Autore beraren esanetan, gizartean eta hezkuntzan ekiteko, pailazo soziohezitzaileak umorea du praktika komunitariorako eta kritikorako tresna nagusi. Halaber, pailazo mota honek, Ventosak (2008) definitzen dituen animazio soziokulturalaren dimentsio pertsonalean, sozialean eta kritikoan eragiten duten giza baloreak eta sentimendu positiboak eta emozio demokratikoak irudikatzen eta transmititzen ditu.

Beste era batera esanda, Ros eta Úcar (2013) autoreek aipatzen duten bezala: dimentsio pertsonalari dagokionez, «se refiere a que la persona adquiere valores de honestidad, aceptación, sinceridad, alegría, entre otros, obteniendo capacidades de disfrute de la vida y cognitivas como imaginar, percibir, razonar» (16.or); dimentsio sozial edo komunitarioari dagokionez, «existe una transmisión de valores humanos y positivos, que consiguen implicar a la persona en la comunidad a través del arte, dotándola de la capacidad para participar en la vida social y en las relaciones» (16. or); dimentsio kritikoari dagokionez, «posibilita ver el otro lado de las cosas, poniendo en duda las jerarquías y leyes, al tiempo que potencia la capacidad de elección» (16.or).

Horrez gain, praktika eta proiektu sozialak burutzen dituzten pailazo hauek, giza baloreen defentsa egiten dute (Ros, 2015a). Horrekin batera, arazoak nola konpondu jakiteko ere balio du pailazogintza mota honek, horretarako porrotaren, gatazkaren eta ahultasunaren lanketaz baliatzen delarik (Medina, Hoyos, Bohórquez, eta Posada, 2015).

\subsection{Euskal Herriko pailazogintzaren azken hamarkadetako ibilbide orokorra}

Arestian ikusi bezala, zirkua eta pailazogintza duela mende asko sortu baziren ere, euskal pailazogintzak duela hamarkada gutxi izan zuen bere abiapuntua. Kixki, Mixki eta Kaxkamelon izan ziren euskaraz antzezten hasi ziren lehen pailazoak, 1972. urtean (Ibargutxi, 2014). Hirukotea gerora, Txirri, Mirri eta Txiribiton bilakatu zen.

Hortaz, euskal pailazogintzak 70eko hamarkadan jarri zuen bere lehen aldarria. Garai hartan ez zegoen euskal dibertsiorik haurrentzat, eta hutsune hori betetzeko bidea pailazo lanetan hastea izan zitekeela pentsatu zuten Kixki, Mixki eta Kaxkamelon pailazoek. Lehen hamahiru urteak he- 
rriz herri ikuskizunak eskaintzen jardun zuten umorearen bidez euskara zabaltzeko helburuarekin, 1982. urtean, Txirri, Mirri eta Txiribiton bilakatu zirelarik (Argia, 1990).

Beren pailazogintza tradizionala zen. Bata (Txirri), pailazo aurpegizuri serioa eta azkarra zen; besteak (Mirri eta Txiribiton), ostera, bihurriak. Pailazook lanak izan zituzten euskararekin, izan ere, Euskal Herri osoarentzat ulergarria zen hizkuntza erabili behar zuten. Hori dela eta, erregistro ezberdinak sortu behar izan zituzten euskara batura joz, baina euskara hotza izan ez zedin ekidinez, haurren hizkeratik hurbilagoa izan zitekeena, lagunartekoa, alegia. Halaber, umore errazaz baliatzen ziren haurren arreta eskuratzeko, beste arlo batzuk (txiste politikoak eta txiste berdeak, besteak beste) ere lantzen zituztelarik, baina beti ere umore intelektualegia erabili gabe (Argia, 1990).

Hamarkada horren amaieran, Kakax, Kokox eta Kirriki pailazo-taldea sortu zen 1979an eta hogei urtez jardun zuten. Halaber, Azkona animazio taldea ere sortu zen orduan, urtebete beranduago; haurrekin, zirkuko teknikak eta gorputz espresioa lantzen hasi zirenean. Euskal Herrian eta Euskal Herritik kanpo aritu ondoren, 1988. urtean Munduko Zirkoko pailazo ikuskizunean parte hartu eta handik jaio ziren 1990. urtean Kiko, Koko, Moko eta Flash, familia nafar batek osaturiko pailazo-taldea, gerora horko kide batzuek alde egin bazuten ere (Ibargutxi, 2014; Argia, 2005).

Aurrekoekin konparatuz, pailazoen izaera aldatuz joan zen (Kiki pailazo jolastia da, Koko alaia eta Moko inozoa), eta berrikuntzak ere ekarri zizkion hasi berri zen euskal pailazogintzari. Ordura arte ez bezala, zirkoko teknika-mota ezberdinak erabiltzen hasi ziren: monozikloa, malabarismoa, mazak, pilotak eta diaboloak besteak beste (Kiki, Koko eta Moko pailazoak, 1980).

Hauen parean sortu ziren baita ere, 90eko hamarkada hastear zegoela, 1987. urtean, Takolo, Pirrutx eta Porrotx pailazoak, gerora Pirrutx joan eta Pirritx batu zitzaielarik: Takolo, Pirritx eta Porrotx osatuz (Ibargutxi, 2014).

Hauek ere euskararen alde egiteko hasi ziren pailazo lanetan LasarteOriako Olentzeroren jaialdi batean, bertako umeak euskararen mundura alaitasunez hurbiltzeko asmoz (Ibargutxi, 2014; Argia, 2005; Goikoetxea, 2016; Unanue, 2012). Baina egun baterako jaio zen pailazo-taldea, herriz herri ikuskizunak eskaintzen aritu zen urte luzez eta hala dihardu oraindik ere.

Arestian esan bezala, Pirrutxek taldea utzi zuen eta 1997an emakume bat sartu zen pailazo lanetan, Euskal Herrian lehenengoz: Pirritx. Urte batzuen buruan, Takolok ere utzi egin behar izan zuen 2004an, eta handik gutxira bigarren emakumea, Marimotots, sartu zen 2007an; gaur egun pailazo-taldea Pirritx, Porrotx eta Marimototsek osatzen dutelarik. Dena den, batu zitzaizkien emakume hauek biek lehendik ere beste pertsonaia batzuk antzezten zituzten ikuskizunetan, eta azpimarratu beharra dago emakumeak sartzeak garrantzia izan zuela, esan bezala, ordura arte Euskal Herrian ez baitzen ohikoa emakumeak pailazo lanetan aritzea (Unanue, 2012). 
1996.urtean, Gari, Montxo eta Joselontxo hirukotea ere sortu zen. Hauek, ordea, beste pailazogintza mota bat landu zuten, pailazogintza klasikoa hautatu baitzuten eta musikariak baitziren. Hortaz, pailazo guztiz klasikoak dira: tronpeta jotzen duen aurpegizuri bat dago (Gari), eta bi augusto (Montxo eta Joselontxo) saxoa eta tuba jotzen dituztenak (Ibargutxi, 2014). Halaber, eskaintzen dituzten ikuskizunak haur nahiz helduentzako ere badira, barrea eragitea beren helburu bakarra delarik (Argia, 2005).

1999an, Korri, Xalto eta Brinko. Euskara tresna nagusitzat hartuz, Lezoko inauteri xelebrea herriko haurren artean gehiago ezagutzera emateko asmoz hasi ziren pailazo lanetan; bertako lekuak, istorioak eta pertsonaia ospetsuak ezagutarazteko, hain zuzen ere. Ildo horretan, hainbat ikuskizun burutu ditu hirukoteak, baita ipuingintza jorratu ere, balio eraikitzaileak sustatzeko asmoarekin (Korri, Xalto ta Brinko, 1999).

2000.urtetik aurrera, makina bat pailazo talde sortu dira. 2001.urtean, estilo klasikoari jarraikiz, Poxpolo eta Mokolo pailazo-bikotea sortu zen,. Urtebete garrenera, Potxin eta Patxin sortu ziren, zirku mundutik hurbilago daudenak. Bestalde, 2002-2003 urte bitartean, gurasoen ibilbidea gertutik ikusita; Txirri, Mirri eta Txiribiton Junior taldea sortu zuten, eta berekin jardun zuten gurasoak erretiratu arte (Argia, 2005).

\section{METODOLOGIA}

\subsection{Aztergaia}

Ikerketa honen aztergaia galdera honetan oinarritzen da: Zein helburu eta ezaugarri ditu ikergai den euskal pailazo-taldearen pailazogintzak? Horrenbestez, galdera horri erantzuteko Takolo, Pirritx, Porrotx eta Marimotots pailazoen proiektu pedagogikoaren sorrera eta garapena aztertu dira. Gaur egun modu aktiboan eta hedapen handiarekin egiten baitute beren zeregina.

Gainera, pailazogintza hezitzaile hauen inguruko ikerketen beharrizana dago: «La investigación científica, la formación y la medición del impacto referente a clown socioeducativo son inexistentes» (Ros, 2015a, 2. or).

\subsection{Diseinua}

Pailazogintza horren sorrera, funtzionamendua eta helburuak aztertzeko, paradigma interpretatiboan kokaturiko ikerketa kualitatibo batean oinarritu da ikerketa. Kualitatiboa hausnarketak eta jarrerak analizatzeko ikerketa mota egokia izan daiteke, ikertuek bizitako esperientzia biltzea nahiago baitu, horrela ikertzaileak beren ikuspuntuak ulertzen baititu (Janesick, 2000). Halaber, ikerketa sozial hau paradigma interpretatiboan aur- 
kitzen da, izan ere, pailazogintza honek haur euskaldunen heziketan duen balioa kulturaren eta egoera historiko baten ondorio dela azaltzen da (Blaxter, Mughes, eta Tight, 2008; Rodríguez, 2011), euskal kulturak eta Euskal Herriaren egoerak zuzenean esku-hartzen baitute fenomeno sozial honen sorrera eta garapena azaltzean.

\subsubsection{Helburuak}

Ikerketaren bilakaera osoan zehar honako helburu hauek hartu dira aintzat:

1. Balizko eredu hezitzaile horren ezaugarriak identifikatzea.

2. Pailazo-taldeak eredu pedagogiko berria sortzen duen konprobatzea.

3. Balizko eredu horrek hezkuntzari egiten dion ekarpena interpretatzea

\subsubsection{Partaideak}

Ikerketa honetan, taldearen sorreratik gaur arte esanguratsuenak izan diren pailazoak (eta hauek interpretatzen dituzten pertsonak) hartu dira kontutan: Takolo, Pirritx, Porrotx eta Marimotots.

\subsubsection{Datu bilketarako tresnak}

Ikerketa hau aurrera eraman ahal izateko, pailazogintza mota honen sorreratik gaurdainoko garapenean izandako aldaketen zergatiak ulertzeko, lau pailazoekin (Takolo, Pirritx, Porrotx eta Marimotots) audioz grabatuak izan diren zenbait ikerketa tresna eta teknika erabili dira:

- Alde batetik, bakarkako sakoneko elkarrizketa komunikatiboak.

- Bestetik, focus groupa, sakoneko talde elkarrizketa komunikatiboa, instrumentu horiek berentzat ere formatzaileak izan direlarik.

- Horrez gain, beren pailazogintzaren eta proiektuen inguruko bi hitzaldi ere hartu dira kontutan; baita haiek sorturiko zenbait euskarriren (ikuskizunak, DVDak, bideoak eta ipuinak, esaterako) eta dokumenturen azterketa egin ere.

\subsubsection{Datuen kategorizazioa}

Datuen kategorizazioa burutzeko, lehenik eta behin, bakarkako elkarrizketa bakoitzetik jasotako informazioaren murrizketa egin da. Halaber, elkarrizketa horietatik jasotako datuak hautatu eta identifikatu dira. Ondoren, datu horietatik abiatuta, informazioaren antolaketa burutu da: elkarrizketatuen erregistroa jaso eta testu zati horiei etiketa bat jarriz, katego- 
rizatuz, alegia. Horrez gain, elkarrizketatu bakoitzaren kategorizazioetik abiatuta, kategorizazio orokorra burutu ahal izateko, talde elkarrizketatik eta hitzaldietatik ere atera dira datuak, kategorizazioaren atala osotu eta borobildu ahal izateko. Horretarako, kategoriak sortzeko, alde batetik, ikerketaren helburuak uneoro abiapuntu izan dira; eta bestetik, ikertzaileak aurretik eginiko diseinuetan, elkarrizketen gidoietan, jaso dituen datuak aintzat hartu dira; izan ere, elkarrizketa bakoitzetik ateratako datuen analisiak berak ere zenbait kategoria sortu ditu, induktiboki, elkarrizketen esperientzietatik kategoria berriak atera ahala.

Gauzak horrela, sorrera, garapena eta hezkuntzari eginiko ekarpena izan dira kategoria nagusiak. Lehenengo kategorian, sorreran, honako azpikategoria hauek aurkitzen dira: pailazo taldearen abiapuntua, pailazogintza mota, pailazogintza aukeratu izanaren arrazoia, erreferenteak eta hasierako helburuak. Bigarrenean, garapenean, eredu pedagogikoaren sorrera azaltze aldera, honako azpikategoria hauek daude: sortzeko modua eta zergatia; eta euskararen normalizazioa eta herrigintza. Horrez gain, beste azpikategoria hauek ere aurkitzen dira bertan: gaur egungo pailazogintzaren helburuak; pailazogintzaren klabeak eta transmititu nahi diren ideiak; garapenaren mugarriak. Hirugarren eta azken kategorian, hezkuntzari eginiko ekarpenean, honako azpikategoria hau ageri da: proiektuak eta material didaktikoa.

Azkenik, kategoria orokorra oinarri izanik, emaitzen analisia eta interpretazioa egin da.

\section{LORTUTAKO EMAITZEN ANALISIA ETA INTERPRETAZIOA}

Erabilitako ikerketa tresnak aintzat harturik, aztertu den hasierako galderari erantzun nahian, lortutako emaitzen analisia eta interpretazioa egin da, hasierako helburuak lortu diren ala ez ikuste aldera. Horretarako, kategorien bidez sailkaturiko jasotako datuon sintesia egin da, emaitzak hobeto ulertze aldera.

Euskal pailazogintzaren ibilbide osoan zehar ez dago pailazogintzaren bidez horrelako ezaugarriak dituen eredu pedagogikorik sortu duen pailazo-talderik, hau da, eredu pedagogiko berria sortu du ikertutako pailazo taldeak; besteak beste, hainbat ezaugarri jasotzen dituzte herrigintzatik; alaitasunaz gain, euskara eta baloreak sustatzen dituzte; gai sozialen lanketa egiteko, egunerokotasunarekin loturiko gaiak hautatzen dituzte; zenbait elkarterekin elkarlanean dihardute; umorearen inguruko ikuspuntu berezia dute; eta sortu duten eredu hezitzailea etengabeko aldaketa- eta hausnarketa-prozesuan dago beti.

«Pailazook (...) ibilbide bat izan degu. Hasi ginan Lasarte-Orian euskararen inguruan herrigintzan. Euskera eta alaitasuna, eta gero balo- 
reak. Eta joan gara ibilbidean ikasten, joan gea zabaltzen, pixkat Euskal Herria zabaldu degu. Euskarri ezberdinak landu ditugu. Eta parte sentitzen gea baita ere gure herriaren euskalgintzan, jarraitzen degu Lasarte-Orian, jarraitzen degu Olentzeron jaialdian, 35 urte pasa ondoren, eta jarraitzen dugu bertako egitasmotan parte hartzen. (...) Badauka ibilbide paralelo bat, (...) baino elkarrekin, gure herriko euskalgintzak duen ibilbidea, gure taldearena, nola ikusten degun herria, nola ikusten degun Euskal Herria.» (E1b, 39:23)

Euskalgintza eta herrigintza bere jardueraren erdigune dira. Euskararekin zerikusirik ez zuten haur haiek euskarara hurbiltzekotan alaitasunetik egin behar zela uste zutelako hasi ziren pailazo-lanetan, beste pailazo klasiko batzuen eskemak erreferentetzat izanik, beste batzuen esperientziak ikusita ideiak hartuz. Hori dela eta, pailazo-taldearen bilakaerak euskarari asko zor diola esan daiteke, gaur egun ere euskalgintzaren barruan kokatzen direlarik.

«Guretzako zan inportantea euskara modu alai batean transmititzea, ze ikastetxetan asignatura zan, \% 80a zan A ereduko ikaslea LasarteOrian, eta haurrentzat zan euskara asignatura bat.

(...) Orduan guk pentsatu genun euskara zabaltzekotan alaitasunetik egin behar genuela, zerbait dibertigarritik egin behar genuela eta guri hori (kar-kar) iruditu zitzaigun pailazogintza bazala (...) horretarako bide on bat. (...) Eta (...) horregatik hasi ginan.» (E1b, 45:14)

«Asko zor diogu euskarari, zor diogu: gure bizimodua, gure ikuskera, gure lanbidea, gure harreman guztiak...» (E1a, 1:54:58)

Bete nahi dituzten helburu nagusiak euskararen normalizazioa, alaitasun hezigarria eta balore hezitzaileak dira. Hasierako helburuen perspektiba mantenduz, gaur egun ere pailazogintzaren bidez alaitasunaren ikuspegi hezitzailea eta euskara sustatzen dihardute. Halaber, hasierako helburuez (euskara eta alaitasuna) gain, eredu pedagogikora eginiko saltoak hirugarren helburu bat lantzeko beharra ekarri zien: baloreak, alegia. Izan ere, lantzen hasi ziren gai sozial horiek zenbait balore transmititzea ere bazekarten berekin, beti ere aurretiko perspektiba hori galdu gabe.

Hori dela eta, pailazoak adi daude egunerokotasuneko gaiei dagokienez, hezitzaile rola dute, hausnarketa egiten dute, gai batzuk diskriminatu egiten dituzte, eztabaida-prozesua izaten dute gauzak erabakitzerako orduan eta gai batzuekiko sentsibilitatea dute.

«Halako gaiak lantzeitugu, (...) gertutik bizitzen ditugunak, herrigintzatik, komunikabideetatik jasotzen ditugunak, iristen zaizkigunak, aportatzen duten gaiak, guri aportatzen digutenak eta aportatu dezaketenak, (...) eta hoiek gizarteratuz indartu ditzazkegunak.» (E1a, 1:55:32) 
Gai sozialak lantzen hasteko dinamika horretan sartuta eta burutzen hasi ziren pailazogintza gizarteko gertakizunetan oinarriturikoa zela ulertuta, baloreen lanketa hori oinarrizko zutabea da tresna pedagogiko bezala beren eredu hezitzailean, izan ere, horrek esan nahi du balore horiek hezitzaile ere sentitzen direlako lantzen dituztela eta horretarako beren eraginaz baliatzen direla.

Elkarte ezberdinekin elkarlanean hastea mugarria izan da. Euskal Herriak, euskarak eta euskal kulturak munduan ere toki bat izan dezaten aldarrikatzen duten heinean, mundu horrek denontzat izan behar duela deritzote. Zentzu horretan, berebiziko garrantzia izan du Euskal Herriko elkarte ezberdinekin lanean aritu izanak. Eta zeresanik ez gaur egun Bizipoza gizarte egitasmoan ere parte-hartzeak, ahulen eta baztertuen ikuspegitik denontzat eginikoa den mundu baten eta Euskal Herri baten aldeko aldarrikapena egiteko balio baitie, elkarte hauen mezuak eta baloreak pailazogintzaren bidez eta euskaraz gizarteratzen dituztelarik.

«Guretzako elkarteekiko lan hori izan da mugarri bat. (...) Ze eman diegu gure lanarekiko, baino umorearekiko, baino bizitzarekiko ere: begirada bat, ikuspegi bat, munduarekikoa, eta Euskal Herritik.» (E1a, $1: 50: 31)$

«Irria Aldizkarian badago apartado bat, kapitulo bat, eskeintzen zaiona elkarteei. Horrela sortu zan, bosgarren hanka honen oinarria hartuta: Irrien Lagunak, bizipoza, auzolan gizartegintza proiektua, elkarteak biltzen zituena, kultur elkarteak.

(...) Denok dauzkagu gabeziak, gaitasunak... elkarri emanez, hartuz... osatzen degu Bizipoza eta denontzako herri bat egiten degu. Eta orduan orain sortu da Bizipoza, dala nolabait, Irrien barruan zegoen hau, hemendik aurrera bazkide gehiago lortuz Irrien Laguna izango da beste bat gehiago bertan. Eta hola izango degu beste indar bat, beste eraginkortasun bat erantzuteko guzti honi.

(...) Iruditzen zaigu, (...) badala Euskal Herria herri bat, non jendeak badaukala dispozizio bat: odola emateko, organoen transplanterako, auzolanerako, ekimienetan modu aktiboan parte hartzeko, laguntzeko. Eta guk egin nahi deguna da gai sozial hauen inguruan eta behar bereziak dituzten haurren, haur hauen elkarteen inguruan, bolondres sare zabal bat lortzea euskaraz funtzionatuko duena. Eta guzti honi indar bat emango diona ta balore hauek gizarteratuko dituena, hortan lagunduko duena.» (E1b, 5:44)

Pailazogintza eraldatzailetzat ikusten duten heinean, elkarteekin lanean hasi izana mugarri oso inportantea izan da taldearentzat eta eredu pedagogikorako bilakaerarentzat: pailazogintza mota berritzaile honen bidez, euskaratik eta alaitasunetik abiatuta, elkarte horien lana eta gai sozial horiek zabaldu eta gizarteratu dituztelako. Ondorioz, pertsonen eskubideak ase- 
betetze aldera, elkarte hauekin eginiko elkarlanaren bidez balore eraldatzaileak lantzea oso garrantzitsua da ikuspegi inklusiboari dagokionez.

Eredu hezitzailearen bilakaera etengabeko aldaketa-prozesua da oraindik ere. Herrigintzatik eta euskalgintzatik elikatzen den pailazo-talde honek sortu duen proiektu hezitzailea autodidaktismoaren bidez sorturikoa izan da neurri handi batean: beren kabuz sortzen zituzten ikuskizunak edo gauza ezberdinak frogatzen joan ahala moldaketak egiten zituzten, besteak beste. Gauzak horrela, sketchak alde batera utzi eta istorioak lantzen hasi ziren, egiten zuten orok ikuspegi hezitzaile batetik bere zergatia izanik.

Hortaz, unearen eta egoeraren arabera burutu den etengabeko aldaketaprozesu bat izan da eredu hezitzailearekiko pailazogintza honen bilakaera osoa eta oraindik ere prozesu amaigabe horretan dihardute, gizartea ere etengabean aldatzen baitoa eta pailazo-talde honen pailazogintza ere gizarte horri egokituz baitoa. Beraz, proiektu pedagogiko hori osatzeko prozesua ez da inoiz amaitzen.

«Etengabeko aldaketan daon gizarte baten barrun funtzionatzen ari gea, eta egon behar degu irekiak datorrenari eta moldatzen jakin horri eta erantzun egokia ematen jakin. Ordun, ideologia (...) finkoa da, hori ezta aldatzen. Baina pentsakerak, hausnarketak, eta esateizut, egunerokotasun horretan bilakaera guzti hoien behatzaile ere bagera. Ordun, gure ideak ere egokituz doaz. (...) Aurrera goaz etengabe, etengabe.» (E3, 26:36)

Horrenbestez, etengabeko aldaketa-prozesuan egoteak, heziketaren ikuspegitik beti ikasteko prest irekiak egoteak, sormenerako aukera ematen die, beharrizan gehiago daudenean, ekarpen gehiago egiteko eta sortzeko premiak agertzen baitira. Beraz, gizartea etengabe aldatzen egoteak eragiten die pailazoei egunerokotasuneko gaiei adi egotea, eta horri moldatuz doaz aldi oro.

Eredu hezitzailea sortzearen arrazoia, etengabeko hausnarketa-prozesuaren ondorio da. Gizartea eta hezkuntza etengabeko aldaketan daudela ondorioztaturik, beren pailazogintzak aldaketa horien isla izan behar zuela zeritzoten, eta horregatik egin zuten eredu hezitzaile baterako hautua, bilakaera hori beharrezkoa ikusten zutelako. Izan ere, pailazogintza ere aldaketa horiei erantzun bat ematen saiatu behar zela uste zuten, gizarte horri moldatuz joan.

«Orain eskolatan eta planteatzen ari diren eredu, eskola eredu aldaketak, espazio zabalagoak, ba pixkat fabrika itxura hori gal dezaten, konfiantza eman, gertutasuna, zurruntasunetik at, zaplazteko eta ostikadetatik eta umearenganako eta familienganako eta txikienganako biolentzatik at... horrek guztiak ere pailazogintzan islada izan behar du eta aspaldi aspertuak geundeke.» (E3, 32:49) 
Gauzak horrela, taldeak sorturiko eredu hezitzailea burutzen duten hausnarketa-prozesu etengabearen ondorioz sortzen da. Hortaz, pailazogintza horrek gogoeta eta ekintza bat hartzen ditu, hau da, etengabeko hausnarketek beren norabidea markatzen dute, eta praktikak balio du gogoeta fintzeko eta norabidea markatzeko.

Euskaldunak izateak, txikitasunak, blaitzen du pailazogintza modalitate hau. Hasiera batean taldea euskararen normalizaziorako premia bezala sortu zen bezalaxe, Euskal Herrian dauden beste beharrizan ezberdinei erantzuna emateko asmotan sortu da eredu pedagogiko hau lantzen duen pailazogintza. Halaber, ezin daiteke pailazo-talde honen bilakaera Euskal Herriko testuingurua aintzat hartu gabe ulertu, Euskal Herriko eragile ezberdinekin izandako hartu-emanetatik elikatzen baita. Hortaz, Euskal Herriaren egoerak eta euskaldun izateak garrantzia du pailazogintza honek izan duen garapena ulertu nahi bada.

«Txikia zarenean, eta hizkuntza minorizatua daukazunean, izokinak bezela, saltoka, korrontean kontra, borroka egin behar dezu, aurrea egin behar dezu. Eta txikia zarenean, eta horrelako, nolabait, herrigintza eta borroka egin behar dezunean, aurrera ateratzeko, enpatia bat sortu dezakezu zu bezela txikiak direnekiko, aldarrikapen hoiekiko. Enpatia lortu dezakezu: genero begirada batekin, emakumeekiko; eta denon artean izango dien harremanekiko; berdintasunezko harremanekiko begirada batekin; ekonomia eredu batekin; o justizia eredu bati begira; edo ekologiari begira; edo munduan dauden harremanei begira. Orduan, nolabait, txikia izateak eman diezaizuke (...) begirada hori, enpatia hori eta ordun, hizkuntza bera, euskera, ez da guretzat bakarrik komunikatzeko tresna bat, (...) da baloreak transmititzen dituen bitarteko bat.» (E1a, 1:50:57)

«Hanka sartu dezakegu, baino azkar ateatzen degu; elkar ezagutzen degu; saretzen gea; auzolana egiten degu... Txikia izateak ere abantaila du eta gure herriak hori ere badu.» (E1a, 1:53:51)

Gauzak horrela, hizkuntza eta kultura eraldatzaileak direla uste dute, eta beren pailazogintza bi arlo horietan, herrigintzan eta euskalgintzan, kokatuta egonik, eredu berri hau ikuspuntu pedagogiko eta eraldatzaile batetik eginda egotea ez da kasualitatea, taldekideak herrigintzan inplikatuta egotea ez den bezala. Hori dela eta, txikitasuna balore oso inportantea bilakatu da haientzat, txikitasun horrek aukera eman baitie beren proiektu hezitzailea sortzerako orduan abantaila izateko: elkarte ezberdinekin elkartzeko aukera izateko, gizarte eta hezkuntzako eragileekin proiektu ezberdinak aurrera eraman ahal izateko, elkarlanean diharduten guztiekin gertutasuna edukitzeko, hainbat balore konpartitzeko...

«Iruditzen zaigu euskaldunok hortan paper berezi bat jokatu dezakegula, badaukagula bentaja bat. (...) Niri etzait iruditzen kasualidadea de- 
nikan, iruitzen zait euskerak ere, euskaldun izateak ematen digula begirada hori, (...) txikitasunak hori emaigula.» (E1a, 1:50:48)

Euskaldunon txikitasun horrekin, enpatia bereganatu dute, gure desabantailetatik abiatuz besteen desabantailak hobeto ulertzen dituztelarik. Enpatia horrek dakarren gizarteko eta hezkuntzako eragile ezberdinekin burutzen duten elkarlana ere herrigintzaren gauzatze bat da, euskaldunok berezko dugun ezaugarria, auzolanarena.

Sortzen duten euskarri oro begirada pedagogiko batetik egina dago. Eredu pedagogikoaren garapenerako dinamikan sartuta, pailazo-taldeak hausnarketa bat egin behar izan zuen gaur eguneko globalizazioari dagokionez. Gauzak horrela, globalizazio horretan euskarari zein leku eskaintzen zitzaion pentsatu zuten. Ondorioz, haurren munduan dauden material (jolasak, arropak, eskolako materialak, besteak beste) eta euskarri (marrazki bizidunak, esaterako) ezberdinetan beste hizkuntzek nagusitasun handiagoa dutela ikusita, haurrek ere mundu horretan euskaraz aritzeko baliabideak behar zituztela hausnartu zuten. Hori dela eta, material eta euskarri ezberdinak euskaraz eskaintzeko beharrizana zegoela pentsatu eta horiek burutzea erabaki zuten.

Horren harira, euskarak mundu horretan ere presentzia izan zezan, Irrien Lagunak Kluba sortu zuten, Irria Aldizkariaren bidez haurrekin zenbait balore (osasuna, natura, zientzia, kultura eta elkartasuna) landu ahal izateko, haurren heziketa euskalduntasunetik bermatzeko aukera izateko.

Horrez gain, beste baliabide batzuk ere eskaini behar zituztela pentsatu zuten, betiere ikuspegi pedagogiko batetik sortzen dituzten produktuok euskal kulturarekin, euskararekin eta emozioekin loturikoak direlarik. Hala, produktuok merchandisingtzat hartu beharrean, produktu kulturaltzat eta didaktikotzat dituzte, hauen xedea ez baita ekonomikoki irabazirik ateratzea edota ospea areagotzea, euskaraz heziketa bermatu ahal izatea baizik.

«Eta gero, ba bai, formalerako ere (...) balio dezaketen gauzak egin ditugu. (...) Ez degu egiten, zerbait didaktikoa bada ere, egiteagatik. Beti dauka... normalean badauka beste zerbait gehiago erantsia. Balio erantsia ematen saiatzen gea.» (E3, 40:40)

Beraz, egiten duten guztiak ikuspegi pedagogiko batetik bere zergatia $\mathrm{du}$, hau da, haurren heziketa bermatu ahal izateko euskarri eta baliabide ezberdinak sortzen dituzte, hezkuntzako esparru guztietan erabilgarri izan daitezkeenak eta mezu sozial ezberdinak zabaltzeko balio dutenak.

Gakoa da proiektuetan beste eragile batzuekin parte-hartzea. Eredu pedagogikodun pailazogintzaren bilakaeran zehar landu dituzten gi- 
zarteko gai guztien lanketarako, elkarteekin eta hezkuntzako eta gizarteko eragile ezberdinekin hartu-emanean egon dira. Horrekin batera, kulturaeta didaktika-produktuez gain, hainbat proiektutan hartu dute parte, hala nola Irrien Lagunak Kluba, Bizipoza, Oinherri, eta Lur eta Amets.

Bizipoza gizarte-egitasmoa euskaraz funtzionatzen duen proiektua da, eta bertan inplikaturik dauden elkarteek transmititzen dituzten baloreak gizarteratzen laguntzen dute pailazogintzaren bidez mezua zabalduz. Bestalde, herrigintzatik, haurren benetako parte-hartzea bultzatzea eta balio hezitzaileak hedatzea helburu duen Oinherri deituriko proiektuan ere inplikaturik dago. Horrez gain, euskararen eta Euskal Herriaren historia zabalduko duen materiala sortzen duen Lur eta Amets proiektuan ere hartzen du parte pailazoen kooperatibak. Horrenbestez, Katxiporreta Kooperatibak pailazo-talde bezala bere lan propioa du, baina beste proiektu batzuetan ere hartzen du parte beste eragile batzuekin elkarlanean. Elkarlanean buruturiko proiektuok: giza eskubideen defentsa egitea, haurren heziketaren ardura gizarte osoarena izatea, heziketa parte-hartzailea eta herritarra izatea eta Euskal Herriak eta euskarak munduan leku propio bat izatea aldarrikatzen dute. Horretarako, erreferente sinboliko eta sozial diren pailazook zeregin garrantzitsua dute proiektuetako ideia horiek guztiak pailazogintzaren bidez zabalduaz.

Hezkuntzari ekarpen ugari egin dizkiote pailazogintza hezigarri honi esker. Hainbat gai sozial eta balore transmititu izan dituzte pailazoek taldearen historian zehar eta hauek guztiak ikuskizunetan landuak izan dira, eta ikuskizunok $D V D$ eetan grabatuak izanik, balore horiek hezkuntza munduan lantzeko aukera eskaini du horrek. Horrekin batera, ikuskizunetan lantzen diren abestiekin ere disko bat atera izan dute urtero eta horrek ere aukera zabala eskaini du ikastetxeetan eta etxeetan abestion bitartez balore eta gai horiek guztiak landu ahal izateko. Halaber, musikaren bidezko eredu pedagogiko hori Imanol Urbietarengandik hartu dute, bera izan baitzen Euskal Herrian aitzindari horretan eta pailazoek ere erreferentetzat hartu zuten bere pedagogia hori.

Gehienetan, hezkuntza mundura eginiko ekarpenen horiek jendartearen eskakizunetatik sorturikoak izan dira, ikusten zituzten beharrizanetatik abiatuta sorturiko proiektuak. Horren adibide dugu Familiak milakolore proiektua, izaera ezberdineko elkarteek familia-eredu mota desberdinak lantzeko baliabide falta zutela-eta sortu zuten karta-jokoa.

Pailazogintza honek eginiko ekarpenak hezkuntza formalean ez ezik, hezkuntza ez-formalean eta informalean ere erabilgarriak izan dira, sortu dituzten produktuek horretarako aukera eskaintzen baitute: gai sozialen eta baloreen lanketarakoa, hain zuzen ere.

«Eskolaz kanpo ere hezteko modu bat. Oso forma errex batean azaltzen diogu hainbat gai, (...) eta beraiek ulertzeko modun, (...) gero eztabaidatzeko etxean ere bai. 
Egia esan, egiten degu ez-formal horretarako, baina errealidadea da ere bai formaletan erabiltzen dituztela gure kantak eta gure bideoak eta gure erreportajeak. Gu konsziente, gea eta pixkat horri begira erebai, ezta egiten deguna, baina bakigu erabiltzen diela. Irakasle askokin topatzen gea eta esaten digute eta eskerrak ematen dizkigutela materialangatik.» $(\mathrm{E} 4,29: 02)$

Laburbilduz, pailazogintza, hezkuntza eta kultura bezalaxe, eraldatzailetzat ikusten dute; eta beren pailazogintza euskal kulturgintzan eta herrigintzan kokatzen duten heinean, nahi duten mundu baten aldeko aldarrikapena egiteko tresna baliagarria izan daitekeela sinesten dute, nahi duten mundu baten aldeko aldarrikapen soziala mundu artistikoaren bidez eginez, jendartea kontzientziatuz. Aldarrikapen hori beti ere ikuspegi komunitario batetik burutzen dute, berdintasunetik, gizarte eta hezkuntza benetan demokratikoak lortzeko asmoaz, Freirek (2005) planteatzen dituen harreman horizontalen bidez eraikitzen dena, zapalduak direnen beharrizanetatik abiaturikoa. Ondorioz, sortu duten eredu hezitzaile honek Pedagogia Kritikoaren erroak dituela esan genezake.

\section{ONDORIOAK}

Pailazo-taldeak eredu pedagogiko berria sortu duela egiaztatu da; horrekin batera, eredu hezitzaile horren ezaugarriak identifikatu dira; eta azkenik, balizko eredu horrek hezkuntzari egiten dion ekarpena interpretatu da.

\subsection{Ondorioen eztabaida}

Pirritx, Porrotx eta Marimotots pailazo-taldea aitzindaria da euskal pailazogintzan eredu pedagogiko bat sortzen. Are gehiago, Euskal Herrian erreferenterik ez izateaz gain, atzerrian ere ez dute halakorik izan, berezko pailazogintza eredua baita, berena, propioa. Dena den, taldeak Ros eta Úcar autoreek (2013) azaltzen dituzten pailazo mota ezberdinekin antzekotasunak baditu ere (ospitaleetara edota herrialde txiroetara bisitak egin dituztelako, adibidez), pailazo sozialarekin du antzekotasun handiena, pailazo soziohezitzailearen modalitatearen barnean kokatuko litzatekeelarik.

Horrenbestez, Ros eta Úcar autoreek (2013) azalduriko pailazo soziohezitzailearen ezaugarriak betetzen dituen lehenengo euskal pailazotaldea da, pailazo mota honen sorreran bere ezaugarri propioak ere badituelarik: herrigintzaren ezaugarriak, hain zuzen ere. Honek esan nahi du, pailazook, pailazo soziohezitzaileak bezala, demokrazia kultural komunitarioa garatzen dutela. 
Ikerketan partaide izan den gizarte eta hezkuntza eremuko euskal pailazo mota berritzaile honek, pailazogintzaren bidez herritartasunaren hobekuntza eta aldaketa soziala bermatu nahi du. Beraz, sortu duten euskal pailazogintzaren bidezko eredu pedagogiko hau oso aproposa da inklusioan eta demokrazian oinarrituriko gizarte bat lortzeko bidean. Horrenbestez, gizarte hori lortu ahal izateko, ezinbestekoa da hezkuntzako esparru guztietan jendarteari horretan kontzientziatzeko eta kritikotasuna bermatzeko aukera eskaintzea; eta pailazo-talde honek eskaintza zabala ematen du txikitatik hausnarketari bide emateko, ikuspegi hezitzaile horrek etengabeko eraldatze-prozesuan egotea eragiten baitie, unean uneko gizarteari moldatuz joanez; eta eragile sozialak diren heinean, beren pailazo-ibilbideari jarraitzen diotenei ikuspegi pedagogiko hori garatzen joateko aukera ere eskaintzen die.

Halaber, euskal sortzaileekin harremanetan egon izanaren eta herrigintzan inplikatuta egotearen ondorio da eredu hezitzaile honen sorrera, gizarteko eta hezkuntzako eragileekin kontaktuan egon izanak errealitateko beharrizan ezberdinak detektatzea eragin baitie: beharrizan horiek asebetetzeko balioko zuen eredu pedagogiko bat sortzeko premia zegoela hausnartuz.

Gogoeta ezberdin horiek guztiek markatu dute pailazogintza mota berritzaile honen norabidea, hain zuzen ere. Pailazoek beren burua eragile sozialtzat hartu zuten unetik, argi ikusi dute hasieratik helburu dituzten euskara eta alaitasuna sustatzeaz gain, gai sozialen eta giza baloreen lanketa burutu behar dutela. Hori dela eta, egunerokotasunari adi egon behar dutela dakite, gizartea etengabe aldatuz doan heinean, beren pailazogintza ere gizarte horri moldatuz baitoa. Horregatik, ikuspegi eraldatzailea behar dute, ikuspegi pedagogikoak hori baitakar berekin, etengabeko prestakuntza- eta eraldaketa-prozesuan egotea, alegia.

Horrenbestez, pailazo ikertzaileak direla esan genezake, izan ere, jendartearentzat esanguratsuak diren gaiak lantzeko, gertutik bizitzen dituzten gizarteko gertakizunak aintzat hartzen dituzte, horien inguruko hausnarketa eginez. Beren eredu pedagogikoaren prozesu horrek, beraz, dinamika bi ditu: gogoeta eta ekintza, praktika- eta hausnarketa-prozesuek elkarri eragiten diotelako. Hau da, egiten dituzten hausnarketa horiek beren norabidea markatzen dute, egindako gogoetetatik bideratzen baitute praktika. Ondorioz, Ikerketa Ekintzaren ikuspegira gerturatzen dira, pailazo ikertzailetzat ere har ditzakegularik. Honek bat egiten du Augusto Boalek (2011) eta beste autore batzuek ${ }^{1}$ diotenarekin: unean uneko testuinguru soziohistorikoa aintzat hartuz, teknika artistikoek gizarteko injustiziak eta egoera latzak salatzeko balio dezaketela, alegia.

1 Ikus 2.1. atala. 
Ondorioz, eztabaida-prozesu baten bitartez erabakitzen dute zein gai landu, eraiki nahi duten munduaren eta Euskal Herriaren aldeko aldarrikapena egiteko, hainbat balore barnebiltzen dituen ideologia zehatz bat zabalduz: norberaren askatasuna errespetatu behar dela; bizitzaren aurrean jarrera baikor bat izan behar dugula; injustiziei aurre egiteko elkarlana behar dugula, denontzako mundu baten alde auzolanean aritu behar dugula; jaiotzen garenetik hiltzen garen arte denok ditugula gaitasunak eta gabeziak, eta horiekin eraikitzen dela bizipoza; bakoitzak bere beharretatik, baina elkarrekin jardun behar dugula, eta ahulen eta baztertuen ikuspegitik bada, askoz hobeto.

Guztiontzako izatea nahi duten mundu horrekiko aldarrikapena egiteko, nahitaezko dute izaera ezberdinetako elkarteekin elkarlanean aritzea, baita euskal kulturarekin lotuta daudenekin edota hezkuntza munduan dihardutenekin. Gauzak horrela, herrigintzaren ezaugarriak garrantzi handia du hezkuntza-prozesuetan, Freirek (2005) proposaturiko ereduan, herri-hezkuntzak komunitatea mobilizatzeko balio duelako. Hori dela eta, Freireren (2005) Zapalduaren Pedagogian oinarrituriko Augusto Boalen (2011) Zapalduaren Antzerkiaren metodologiarekin ere antzekotasun handiak ditu pailazo-talde honen ereduak, hau ere praktika pedagogiko berritzailea baitugu, haurrak eta familiak pailazogintzaren bidez zenbait gairen inguruan kontzientziatzeko balio duena, errealitatearekiko kritikotasuna bermatuko duena, beti ere zapaldurik gabeko gizarte demokratiko baten aldeko apustua eginez.

Horren harira, euskaldun izateak, txikitasunak, zerikusi handia izan du pailazogintza honen sorreran, txikia edo zapaldua izateak gauza berriak sortzeko premia eragiten baitu, beharrizanei modu ezberdinean aurre egitea. Halaber, heziketan giza harremanen horizontaltasuna, zapalduak zapaltzailearen estrukturetatik at daudenean ematen baita.

Hori dela eta, pailazogintzaren bidez euskal gizartea ahalduntzen dutela esan daiteke, berek aurretiaz eginiko gogoetetatik abiatutako beren praktikaren bidez, jendartea kontzientziatzen baitute, nahi duten mundu justu eta orekatu bat izateko hausnartzera bideratuz. Hori dela eta, beren ikuskizunez gain, sortzen dituzten produktu kultural, euskarri, material didaktiko edota elkarlanaren bidez burutzen duten proiektu orok berebiziko garrantzia du hezkuntzari dagokionez, hauek guztiak hezkuntzako esparru guztietan (informalean, formalean eta ez-formalean) baliabide oso baliagarri baitira.

Ondorioz, beren pailazogintza praktika pedagogiko bilakatu da, herrigintzatik jaioa, herrigintzatik elikatua eta herrigintzari nahi duten mundu eta Euskal Herri justu baten aldeko aldarrikapena egiteko aukera eskaintzen duena, eta beraz, ezin da Euskal Herriko testuingurutik at ulertu. Horrek esan nahi du, pailazogintzaren bitartez mundua alda daitekeela sinesten dutela, hots, jendearengan duten eraginaz baliatuz, heziketa lana egite dute pailazogintzaren bidez. 


\subsection{Etorkizuneko lan-ildoak}

Ikerketa honen emaitzak eta ondorioak aintzat hartzen badira, horiek gizartean zein hezkuntzako esparru ezberdinetan izan dezaketen inplikazioaz hausnartu daiteke, jarraian etorkizunean ikerketa lerro berriak irekitzen direlarik:

- Beren dokumentuen, euskarrien, materialen eta produktu kultural eta didaktikoen azterketa sakonagoa egitea aproposa izango litzateke, horietan aurkitzen baitira beren ekarpen guztiak eta heziketarako baliabide egokiak izan daitezke.

- Parte hartzen duten proiektuen (Irrien Lagunak Kluba, Bizipoza, Oinherri, Lur eta Amets, besteak beste) analisi sakonagoa ere egin beharko litzateke, eragile ezberdinekin burutzen dituzten proiektuok ere beren proiektu pedagogikoaren sorreran eragin handia duten heinean. Horrenbestez, euskal pailazogintza mota berritzaile honek hezkuntzari egiten dion ekarpena sakonago eta osatuago baloratu beharko litzateke, izan ere, ikuspegi komunitarioaren eta demokratikoaren mesedetan burutzen den tresna pedagogikoa da.

- Gauzak horrela, herri izaeratik sortutako horrelako proiektuek izan dezaketen inpaktua aintzat hartzen bada, horrelako proiektuak gehiago ikertu behar direla ondoriozta daiteke, etorkizunerako ikerketa-ildoei dagokienez, sakonago azter daitezen pailazogintza mota honek hezkuntzari eta herrigintzari, euskararen normalizazioari eta euskal kulturari- egiten dizkien ekarpenak.

\section{ERREFERENTZIAK}

Alcántara, A., Llotje, T., eta Lopez, J. (2009). El circo social una herramienta educativa y transformadora. Barcelona: Bido Nou Barris.

Argia. (1990ko azaroaren 25a). Ez gara artista eta ez aktore, saltsero baizik. Argia. http://www .argia.eus/argia-astekaria/1314/xabier-otaegi-eta-jose-ignazioansorena -tik berreskuratua.

Argia. (2005eko azaroaren 06a). Sudur gorrien tribua. Argia. http://www.argia. eus/argia-astekaria/2014/sudur-gorrien-tribua -tik berreskuratua

Blaxter, L., Mughes, C., eta Tight, M. (2008). ¿Cómo se investiga? . Barcelona: Grao.

Boal, A. (2011). Teatro del oprimido. Cuadernos de pedagogía, (411), 46-51.

Ceballos, E. (1999). El libro de oro de los payasos. Los más famosos y divertidos sketches de circo. (Trad. Margherita Pavia). México: Col. Escenología.

Circo en acción. (2017). El Circo hace escuela. Río Cuarto, Argentina: http:// www.circoenaccion.com/escuela/ -tik berreskuratua.

Crowther, C. (1979). Payasos y payasadas. Bogotá: Voluntad Editores Ltda.

Domínguez, A. (2015). La vulnerabilidad tras la risa. Revista cultural de nuestra América, (22), 87. 
Fo, D. (2008). Manual mínimo del actor (Trad. Carla Matteini). México: Ediciones el Milabro-UANL.

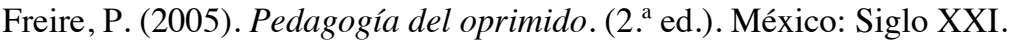

Goikoetxea, G. (2016ko abuztuaren 4a). Ereindakoaren fruituak ontzen hasteko garaia. Berria. http://www.berria.eus/paperekoa/1924/004/001/2016-08-04/ ereindakoaren_fruituak_ontzen_hasteko_garaia.htm -tik berreskuratua

Guarnizo, M. (2013). El payaso: recreación y educación en una sola experiencia. Bogotá: Universidad Pedagógica Nacional

Ibargutxi, F. (2014). Pailazo guztiak Mokolo gogoan. Diario Vasco. http:// Www .diariovasco.com/v/20100417/cultura/pailazo-guztiak-mokolo-gogoan20100417.html -tik berreskuratua.

Janesick, V. (2000). La danza del diseño de la investigación cualitativa: metáfora, metodolatría y significado. En Denman, C., y Haro, J. (Comps.), Por los rincones. Antología de métodos cualitativos en la investigación social. México: El Colegio de Sonora.

Jara, J. (2011). Los juegos teatrales del clown: navegante de las emociones. Buenos Aires: Ediciones Novedades Educativas.

Kiki, Moko eta Koko (1980). Kiko, Moko eta Koko pailazoak. 2017ko urtarrilean berreskuratua, http://www.kikikokomoko.com/ ataritik.

Korri, Xalto eta Brinko (1999). Korri, Xalto ta Brinko pailazoak. 2017ko urtarrilean berreskuratua, http://www.korrixaltotabrinko.com/ ataritik.

López, M. (2016). La adquisición de habilidades sociales a través del arte del clown (Master Amaierako Lana). Universidad de Cantabria: Facultad de Educación, Santander.

Medina, D. M., Hoyos, J. M., Bohórquez, L. F., eta Posada, R. A. (2015). El clown una herramienta pedagógica. Un acercamiento a las prácticas de resiliencia desde los procesos de creación teatral de los jóvenes de la Corporación Polichinela (Lizentziatura tesia). Universidad de Antioquia: Facultad de Arte, Medellín.

Medina, R., eta Citlalli, Z. (2015). Hacia una definición del payaso (Doktore tesia). Universidad Autónoma de Querétaro, México.

Molina, M. (2005). Teatro del oprimido, una herramienta de intervención social. (Tesis para optar a Grado de licenciado en Educación). Universidad Austral de Chile, Facultad de Filosofía y Humanidades.

Nicoll, A. (1977). El mundo de arlequín. Estudio crítico de la Commedia dell'Arte. Barcelona: Barral editores.

Rodríguez, J. M. (2011). Métodos de investigación cualitativa. Revista de Investigación Silogismo, 1(08).

Ros, F. J. (2015a). La formación de profesionales del clown socioeducativo: una propuesta futura. En Pedagogía social, universidad y sociedad (65-71). Universidad Nacional de Educación a Distancia, UNED.

Ros, F. J. (2015b). Cómo reivindicar derechos humanos a través del arte del clown: La función social en el payaso. Revista de educación social. http:// www .eduso.net/res/20/articulo/como-reivindicar-derechos-humanos-a-travesdel-arte-del-clown-la-funcion-social-en-el-payaso- -tik berreskuratua.

Ros, F. J., eta Úcar, X. (2013). Aportes para la definición, caracterización y expansión de un «clown socioeducativo». En O. G. Susana (Torío López), La crisis 
social y el estado del bienestar: las respuestas de la Pedagogía Social (669677). Oviedo: Ediciones Universidad de Oviedo.

Sáinz, J. (1990). Cuaderno de Circo. Madrid: Gráficas Caro.

Unanue, M. (2012ko azaroaren 25a). Muxu eta irrien filosofia. Berria. http://www. berria.eus/paperekoa/1658/046/001/2012-11-25/muxu_eta_irrien_filosofia. htm -tik berreskuratua.

Ventosa, V. J. (2008). Perfiles y modelos de Animación y tiempo libre. Madrid: Editorial CCS. 